\title{
Seasonal Impact on the Minerals of Jamunapari Goat Milk Minerals under Field and Farm Rearing Condition
}

\author{
Gitam Singh $^{1 *}$ and R.B. Sharma ${ }^{2}$ \\ ${ }^{1}$ Animal Science, K.V.K., Tonk, Rajasthan - 304022, India \\ ${ }^{2}$ National Agricultural Higher Education Project (NAHEP), ICAR, New Delhi, 110012, India \\ *Corresponding author
}

\section{A B S T R A C T}

The seasonal effect on calcium content was significantly different in Jamunapari goat breed milk under field and farm rearing conditions at 5\% level of significance. The phosphorus per cent was found to be $0.117 \pm 0.0012$ and $0.120 \pm 0.0010,0.119 \pm 0.0011$ and $0.122 \pm 0.0010$ and $0.124 \pm 0.0010$ and $0.127 \pm 0.0012$, respectively. The potassium per cent in Jamunapari breed under field and farm rearing conditions for rainy, winter and summer seasons was found to be $0.108 \pm 0.0008$ and $0.110 \pm 0.0010,0.110 \pm 0.0009$ and $0.111 \pm 0.0009$

\section{Keywords}

Season, Minerals of Jamunapari, Goat Milk, Field and Farm.

\section{Article Info}

Accepted:

17 July 2017

Available Online:

10 September 2017 and $0.112 \pm 0.0007$ and $0.112 \pm 0.0011$ per cent, respectively. The magnesium percentage in the milk of Jamunapari goat breed under filed and farm rearing conditions for aforesaid seasons, the magnesium per cent was found to be $0.0138 \pm 0.00018$ and $0.0147 \pm 0.00018$, $0.0144 \pm 0.00012$ and $0.0151 \pm 0.00014$ and $0.0150 \pm 0.00017$ and $0.0158 \pm 0.00016$, respectively. The chloride per cent was found to be $0.100 \pm 0.0006$ and $0.104 \pm 0.0006$, $0.102 \pm 0.0004$ and $0.106 \pm 0.00049$ and $0.104 \pm 0.0006,0.108 \pm 0.0006$, respectively. The overall average chloride content of all samples of milk was $0.106 \pm 0.0006$ per cent. Our results on chloride content presented variation in chloride content under field and farm rearing conditions was observed to be significantly in milk. The selenium per cent was found to be $0.01640 \pm 0.000056$ and $0.01628 \pm 0.00006,0.01660 \pm 0.00006$ and $0.01648 \pm 0.00007$ and $0.01680 \pm 0.00048$ and $0.01668 \pm 0.00005$, respectively. The highest selenium percentage was recorded in winter seasons either field or farm rearing conditions. The statistical analysis also revealed that the effect of seasons on selenium content was significantly higher in Jamunapari goat breed milk under field and farm rearing conditions at $1 \%$ level of significance. The calcium, phosphorus, potassium, magnesium and chloride percentage in the milk of Jamunapari goat breeds under farm rearing conditions was significantly higher than that of field rearing conditions. Season had conspicuous effects on milk quality of goats under study.

\section{Introduction}

Goat which was known as "Wet nurse of infant" in the United Kingdom and "Poor man's cow" in India was the first animal to be domesticated (Zeuner, 1963). Goats were among the earliest species of livestock to be domesticated approximately 9000 years ago.
These small ruminants descended from the Bezoar or wild goat (Capra hircus) in the hills of western Asia (Casey and Webb, 2010). The consequence of domestication was a change in the phenotypic characteristics of wild goats, which resulted in the development 
of a multiplicity of goat breeds or types. These breeds or types were distributed across the world as a result of the migration and translocation of humans, usually due to changing climatic conditions and natural resources. The world goat population now consists of an enormous amount of genetic variation in morphological and production characteristics (Galal, 2005; Shrestha et al., 2005). According to the Food and Agriculture Organization of the United Nations (FAO, 1999), there are now about 570 breeds of goats in the goat database. The domestication of goats signaled the start of goat production in different systems and placed significant responsibility on goat keepers; hence the need to study and understand goat production systems, as well as the quality of products from animal origin.

Goat population in the world was 464,323000 in $1980 ; 591,367000$ in $1990 ; 746,689000$ in $2000 ; 864,394000$ in $2008 ; 1,183$ goat breeds; $6,674,801000$ human populations in 2008 . Goat population in India was 86,900000 in $1980 ; 113,200000$ in $1990 ; 123,533000$ in $2000 ; 125,732000$ in 2008; 39 goat breeds; $1,139,965000$ human population in 2008; 1,080 US\$ gross national income per capita (Shrestha et al., 2010, 2011).

The strong Roman nose renders the upper jaw and lip in many Jamunapari shorter than the lower jaw, the condition being called an "undershot upper jaw" or brachygnathia, it causes a challenge for this goat to feed on grasses growing on ground. It is the tallest breed, commonly known as the "Pari"(Angel) due to its splendid appearance. Its home tract and natural habitat is the Chakarnagar area of the Etawah district in the State of Uttar Pradesh, along the delta of the Jamuna and Chambal Rivers, and the Bhind district of the State of Madhya Pradesh along the Kaweri River, east of New Delhi. Female Jamunapari weigh around $2.7 \mathrm{~kg}$ at birth, $13.6 \mathrm{~kg}$ at six months, and $29.4 \mathrm{~kg}$ at 12 months of age. Male kids have significantly higher body weights. Growth rate averages about $0.9 \mathrm{~kg}$ per week up to three months of age, and $0.9 \mathrm{~kg}$ per 10 days thereafter (Rout et al., 2004). Due to present deforestation and land reclamation, the original home tract with its brush vegetation is now becoming greatly changed to the disadvantage of the browsing Jamunapari, and thus contributing to the endangerment of the Jamunapari breed.

\section{Materials and Methods}

The study was conducted at the central institute for research on goats, Makhdoom, Mathura; under the division nutrition feed resources and products technology for the study of farm rearing condition. Milk samples were collected from Jamunapari goat under the farm and field rearing condition. Field samples were collected from different villages. The Jamunapari breed milk samples were from villages of Mathura and Agra, India $\left(27^{\circ} 10^{\prime} \mathrm{N}, 78-\mathrm{o} 002^{\prime} \mathrm{E}\right.$ and $169 \mathrm{~m}$ above MSL).

Geologically the Institute is situated under Yamuna river semi-arid soil. Temperature ranges between $60 \mathrm{C}$ in winter to as high $45^{\circ}$ $\mathrm{C}$ in summer. Annual average rainfall is a period of 50 - 60 days. Monsoon arrives in mid-July and remains active till midSeptember Agnihotri and Rajkumar (2007).

The methodology used was an adaption from Bourbouze (1995) and Alvarez Funes and Paz Motola (1997).

\section{Experimental goats and management}

A total of 479 milk samples were collected from field and farm rearing condition 106 summer (field 26 and farm 80), rainy 255 (field 18 and farm 237) and winter 118 (field 58 and farm 60) milk samples. 


\section{Sample collection and analysis}

Goat milk samples were collected from research farm and field properly at varied environmental conditions and seasons (summer, rainy and winter). Determination of minerals was followed (Magnesium and Selenium) by Atomic Absorption Spectrophotometer (AAS), determination of Calcium and Potassium by Flame Technique and Phosphorus and Chloride by chemical methods (Fig. 1).

\section{Results and Discussions}

The calcium per cent was found to be $0.142 \pm 0.0018$ and $0.148 \pm 0.0018$, $0.146 \pm 0.0019$ and $0.150 \pm 0.0019$ and $0.147 \pm 0.0019$ and $0.155 \pm 0.0020$ in the milk of Jamunapari breed under field and farm rearing conditions for rainy, winter and summer seasons, respectively. Our results on calcium per cent presented in table 1 revealed that variation in calcium content under field and farm rearing conditions was observed significantly. Our result further showed that highest calcium content was found in winter seasons under field as well as farm rearing conditions. It is observed from the ANOVA table that the seasonal effect on calcium content was significantly different in Jamunapari goat breed milk under field and farm rearing conditions at 5\% level of significance (Table 2).

The phosphorus per cent was found to be $0.117 \pm 0.0012$ and $0.120 \pm 0.0010$, $0.119 \pm 0.0011$ and $0.122 \pm 0.0010$ and $0.124 \pm 0.0010$ and $0.127 \pm 0.0012$, respectively. These data suggested that phosphorus content was highest in winter seasons and lowest in summer seasons in goat milk under field and farm rearing conditions. It is also observed from our present study that phosphorus per cent in the milk under field rearing conditions was lower than that of farm rearing conditions in all above seasons. The results obtained on phosphorus content from present investigation in the milk of Jamunapari goat breeds under field and farm rearing conditions under different seasons are fully corroborated with the findings of Pal et al., (2011).

The potassium per cent in Jamunapari breed under field and farm rearing conditions for rainy, winter and summer seasons was found to be $0.108 \pm 0.0008$ and $0.110 \pm 0.0010$, $0.110 \pm 0.0009$ and $0.111 \pm 0.0009$ and $0.112 \pm 0.0007$ and $0.112 \pm 0.0011$ per cent, respectively.

The highest potassium percentage was recorded in winter seasons either field or farm rearing conditions. The statistical analysis also revealed that the effect of seasons on potassium content was significantly different in Jamunapari goat breed milk under field and farm rearing conditions at 5\% level of significance.

The magnesium percentage in the milk of Jamunapari goat breed under filed and farm rearing conditions for aforesaid seasons, the magnesium per cent was found to be $0.0138 \pm 0.00018$ and $0.0147 \pm 0.00018$, $0.0144 \pm 0.00012$ and $0.0151 \pm 0.00014$ and $0.0150 \pm 0.00017$ and $0.0158 \pm 0.00016$, respectively. The statistical analysis revealed that magnesium content under field rearing conditions in Jamunapari goat breed milk in all seasons was significantly lower than that of farm rearing samples. The highest magnesium content was observed in winter seasons under field as well as farm rearing samples. The ANOVA Table also revealed that the effect of seasons on magnesium content was significantly different in Jamunapari goat breed milk under field and farm rearing conditions at $1 \%$ level of significance. 
Fig.1 Collection of milk samples and analysis
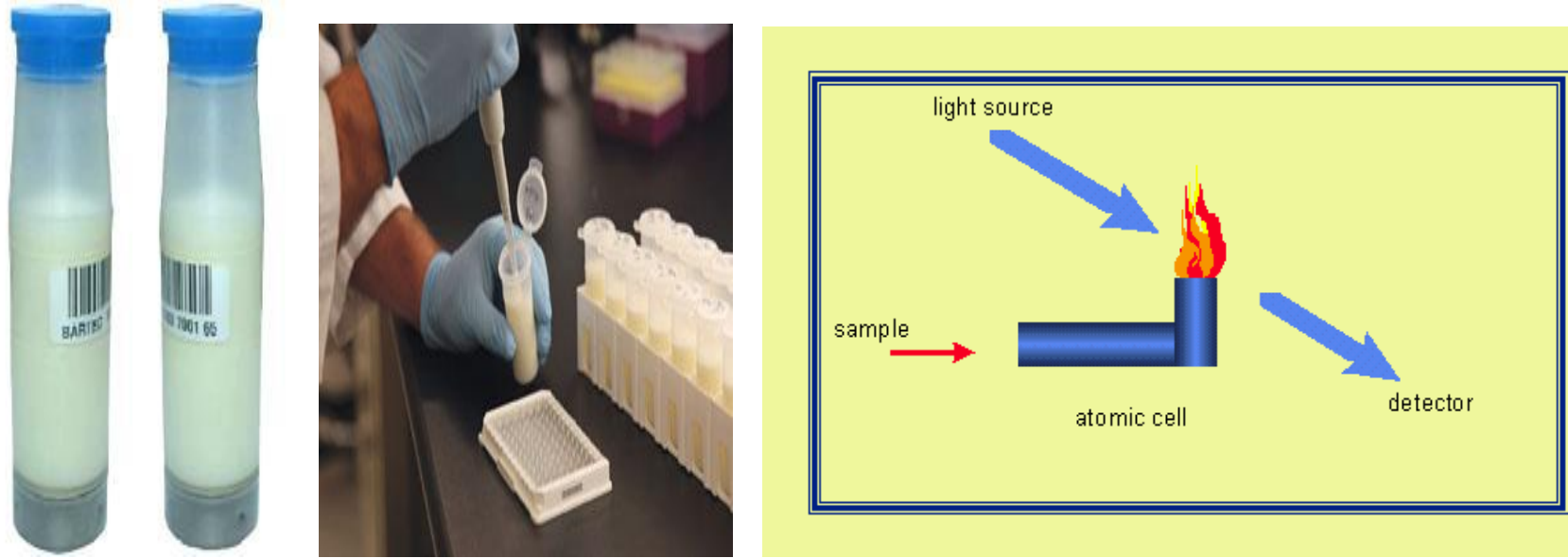

Table.1 Effect of season on the percentage of milk minerals components of Jamunapari goats under field and farm rearing conditions

\begin{tabular}{|c|c|c|c|c|c|c|}
\hline $\begin{array}{l}\text { Sl. } \\
\text { No. }\end{array}$ & $\begin{array}{l}\text { Component of } \\
\text { goat milk }\end{array}$ & Field & Farm & $\begin{array}{l}\text { Overall } \\
\text { Average }\end{array}$ & $\begin{array}{l}\text { Test of } \\
\text { signific. }\end{array}$ & $\begin{array}{l}\text { Table value } \\
\text { (t) } 5 \% 1 \%\end{array}$ \\
\hline 1 & $\begin{array}{l}\text { Calcium } \\
\text { (i) Summer } \\
\text { (ii) Rainy } \\
\text { (iii) Winter }\end{array}$ & $\begin{array}{l}0.142 \pm 0.0018 \\
0.146 \pm 0.0019 \\
0.147 \pm 0.0019\end{array}$ & $\begin{array}{l}0.148 \pm 0.0018 \\
0.150 \pm 0.0019 \\
0.155 \pm 0.0020\end{array}$ & $\begin{array}{l}0.145 \pm 0.0018 \\
0.148 \pm 0.0019 \\
0.151 \pm 0.0019\end{array}$ & $\begin{array}{l}3.023^{++} \\
1.881^{\mathrm{NS}} \\
4.319^{++}\end{array}$ & 1.9602 .576 \\
\hline 2 & $\begin{array}{l}\text { Phosphorus } \\
\text { (i) Summer } \\
\text { (ii) Rainy } \\
\text { (iii) Winter }\end{array}$ & $\begin{array}{l}0.117 \pm 0.0012 \\
0.119 \pm 0.0011 \\
0.124 \pm 0.0010 \\
\end{array}$ & $\begin{array}{l}0.120 \pm 0.0010 \\
0.122 \pm 0.0010 \\
0.127 \pm 0.0012 \\
\end{array}$ & $\begin{array}{l}0.1185 \pm 0.0011 \\
0.1205 \pm 0.0010 \\
0.1255 \pm 0.0010 \\
\end{array}$ & $\begin{array}{l}2.112^{+} \\
2.204^{+} \\
2.196^{+} \\
\end{array}$ & 1.9602 .576 \\
\hline 3 & $\begin{array}{l}\text { Potassium } \\
\text { (i) Summer } \\
\text { (ii) Rainy } \\
\text { (iii) Winter }\end{array}$ & $\begin{array}{l}0.108 \pm 0.0008 \\
0.110 \pm 0.0009 \\
0.112 \pm 0.0007\end{array}$ & $\begin{array}{l}0.110 \pm 0.0010 \\
0.111 \pm 0.0009 \\
0.112 \pm 0.0011\end{array}$ & $\begin{array}{l}0.1090 \pm 0.0008 \\
0.1105 \pm 0.0009 \\
0.112 \pm 0.0009\end{array}$ & $\begin{array}{l}1.903^{\mathrm{NS}} \\
1.816^{\mathrm{NS}} \\
1.031^{\mathrm{NS}}\end{array}$ & 1.9602 .576 \\
\hline 4 & $\begin{array}{l}\text { Magnessium } \\
\text { (i) Summer } \\
\text { (ii) Rainy } \\
\text { (iii) Winter }\end{array}$ & $\begin{array}{l}0.0138 \pm 0.00018 \\
0.0144 \pm 0.00012 \\
0.0150 \pm 0.00017\end{array}$ & $\begin{array}{l}0.0147 \pm 0.00018 \\
0.0151 \pm 0.00014 \\
0.0158 \pm 0.00016\end{array}$ & $\begin{array}{l}0.0143 \pm 0.00018 \\
0.0147 \pm 0.00013 \\
0.0154 \pm 0.00016\end{array}$ & $\begin{array}{l}7.810^{++} \\
6.314^{++} \\
6.963^{++}\end{array}$ & 1.9602 .576 \\
\hline 5 & $\begin{array}{l}\text { Chloride } \\
\text { (i) Summer } \\
\text { (ii) Rainy } \\
\text { (iii) Winter }\end{array}$ & $\begin{array}{l}0.100 \pm 0.0006 \\
0.102 \pm 0.0004 \\
0.104 \pm 0.0006\end{array}$ & $\begin{array}{l}0.104 \pm 0.0006 \\
0.106 \pm 0.00049 \\
0.108 \pm 0.0006\end{array}$ & $\begin{array}{l}0.102 \pm 0.0006 \\
0.104 \pm 0.00048 \\
0.106 \pm 0.0006\end{array}$ & $\begin{array}{l}2.469^{+} \\
2.509^{+} \\
2.341^{+} \\
\end{array}$ & 1.9602 .576 \\
\hline 6 & $\begin{array}{l}\text { Selenium } \\
\text { (i) Summer } \\
\text { (ii) Rainy } \\
\text { (iii) Winter }\end{array}$ & $\begin{array}{l}0.01640 \pm 0.0000 \\
6 \\
0.01660 \pm 0.0000 \\
6 \\
0.01680 \pm 0.0000 \\
5\end{array}$ & $\begin{array}{l}0.01628 \pm 0.00006 \\
0.01648 \pm 0.00007 \\
0.01668 \pm 0.00005\end{array}$ & $\begin{array}{l}0.01634 \pm 0.00005 \\
8 \\
0.01654 \pm 0.00006 \\
0.01674 \pm 0.00005\end{array}$ & $\begin{array}{l}6.314^{++} \\
5.963^{++} \\
5.063^{++}\end{array}$ & 1.9602 .576 \\
\hline
\end{tabular}

NS=Non Significant

$++=$ Significant at $\mathrm{p}<0.05$

$+=$ Significant at $5 \%$ level of significance 
Table.2 ANOVAs for the effect of season on goat milk under field and farm rearing conditions

\begin{tabular}{|c|c|c|c|c|}
\hline \multirow[t]{2}{*}{ Contents for the source of variance } & \multicolumn{2}{|c|}{ Variance ratio } & \multicolumn{2}{|c|}{ F- Value table } \\
\hline & Field & Farm & $5 \%$ & $1 \%$ \\
\hline Calcium & $3.116^{+}$ & $3.347^{+}$ & 3.00 & 4.610 \\
\hline Phosphorus & $4.219^{+}$ & $4.600^{+}$ & 3.00 & 4.610 \\
\hline Potassium & $3.966^{+}$ & $4.341^{+}$ & 3.00 & 4.610 \\
\hline Magnesium & $6.316^{++}$ & $3.259^{++}$ & 3.00 & 4.610 \\
\hline Chloride & $3.214^{+}$ & $3.679^{+}$ & 3.00 & 4.610 \\
\hline Selenium & $4.630^{++}$ & $3.880^{++}$ & 3.00 & 4.610 \\
\hline
\end{tabular}

The chloride per cent was found to be $0.100 \pm 0.0006$ and $0.104 \pm 0.0006$, $0.102 \pm 0.0004$ and $0.106 \pm 0.00049$ and $0.104 \pm 0.0006, \quad 0.108 \pm 0.0006$, respectively. The overall average chloride content of all above samples of milk was $0.106 \pm 0.0006$ per cent. Our results on chloride content presented in above Table revealed that variation in chloride content under field and farm rearing conditions was observed to be significantly in milk. The above table further showed that highest chloride content in milk was found in winter season irrespective of field or farm rearing conditions. The statistical analysis also revealed that the effect of seasons on chloride content was significantly different in Jamunapari goat breed milk under field and farm rearing conditions at $1 \%$ level of significance.

The selenium per cent was found to be $0.01640 \pm 0.000056$ and $0.01628 \pm 0.00006$, $0.01660 \pm 0.00006$ and $0.01648 \pm 0.00007$ and $0.01680 \pm 0.00048$ and $0.01668 \pm 0.00005$, respectively. It is observed from above table that selenium content was significantly greater in field samples than farm rearing samples in all seasons.

The highest selenium percentage was recorded in winter seasons either field or farm rearing conditions. The statistical analysis also revealed that the effect of seasons on selenium content was significantly higher in Jamunapari goat breed milk under field and farm rearing conditions at $1 \%$ level of significance.
The value reported by $\mathrm{Pal}$ et al., (2011) for seasonal effect on potassium content in above goat breed's milk support results of present study. Magnesium in different seasons in the milk of Jamunapari goat breed is in fair agreement with the findings of $\mathrm{Pal}$ et al., (2011) for Indian goat breeds. Our results on chloride in different seasons in the milk Jamunapari goat breed are in fair agreement with the findings of Adesina (2012) who reported that the essential minerals like $\mathrm{Ca}, \mathrm{K}$, $\mathrm{P}, \mathrm{Na}, \mathrm{Fe}, \mathrm{Mg}, \mathrm{Mn}, \mathrm{Zn}$ and $\mathrm{Cu}$ were detected in measurable concentrations ranging from 0.05 to $1.53 \mathrm{mg} / 1,0.06$ to $151.5 \mathrm{mg} / 1$ and 0.09 to $1445 \mathrm{mg} / 1$ for $\mathrm{WF}, \mathrm{RB}$ and MT breeds respectively. The result showed that breed of cow has no significant effect on the mineral and amino acids composition of the milk. Generally, the compositional variation of milk under study typified those of dairy herds earlier reported.

The calcium, phosphorus, potassium, magnesium and chloride percentage in the milk of Jamunapari goat breeds under farm rearing conditions was significantly higher than that of field rearing conditions. Season had conspicuous effects on milk quality of goats under study.

\section{References}

Adesina, K., 2012. Effect of Breed on the Composition of Cow Milk under Traditional Management Practices in Ado-Ekiti, Nigeria, J. Appl. Sci. Environ. Manage, 16(1): 55 - 59. 
Agnihotri, M.K., and Rajkumar V. 2007. Effect of breed, parity and stage of lactation on milk composition of western region goats of India. International Journal of Dairy Science 2007; 2 (2):172-177.

Alvarez Funes, R., and Paz Motola, R. 1997. Metodolog'ýaasociada al diseño de propuestaspara el desarrollo de la producciónlecheracaprina (Associated methodology for the design of proposals for development of milk goat production). Archivos de Zootecnia 1997; 46:211-224.

Bourbouze, A., Goat production system study methods. In: El Aich, A., Landau, S., Borbouze, A., Rubino, R., MorandFehr, P. (Eds.) 1995. Goat Production Systems in the Mediterranean, vol. 71. EAAP Publication, Wageningen Pers, Wageningen, pp. 1995; 6-19.

Casey, N.H., and Webb E.G. 2010. Managing goat production for meat quality. Small Ruminant Research 2010; (89)2:18-224.

FAO. 1999. Food and Agricultural Organization, United Nations <http: //faostat.fao.org/site/339/default.aspx >.1 999

Galal, E.S.E., 2005. Biodiversity in goats.
Small Ruminant Research. 2005; (60):75-81.

Pal, U.K., Mandal, P.K., Rao, V.K. and Das, C.D. 2011. Quality and Utility of Goat Milk with Special Reference to India: An Overview. Asian Journal of Animal Sciences, 2011; 5: 56-63.

Rout, P.K., Mandal A. Singh M.K. Roy, R. Sharma, N. and Haelein, G.F.W. 2004. Jamunapari a dairy goat breed in India, www.dairygoatjournal.com, 2004; 209, $85,175,9$.

Shrestha, J.N.B., and Fahmy, M.H. 2005. Breeding goats for meat production: a review. 1. Genetic resources, management and breed evaluation. Small Ruminant Research, 2005; 58:93106.

Shrestha, J.N.B., and Galal, E.S.E. 2010. Conservation of goat genetic resources. In: Solaiman, S. (ed.) Goat Science and Production. Wiley-Blackwell, Ames, IA, USA, pp. 2010; 39-53.

Shrestha, J.N.B., and Galal, E.S.E. 2011. Conservation of goat genetic resources. Small Ruminant Research 2011.

Zeuner, F.E., 1963. A History of domesticated Animals. London, Hutchinson. 1963.

\section{How to cite this article:}

Gitam Singh and Sharma, R.B. 2017. Seasonal Impact on the Minerals of Jamunapari Goat Milk Minerals under Field and Farm Rearing Condition. Int.J.Curr.Microbiol.App.Sci. 6(9): 1298-1303. doi: https://doi.org/10.20546/ijcmas.2017.609.156 